\title{
Globalization and economic development in Zimbabwe: A new model for sustainable development.
}

\author{
Mr John Mpofu; \\ Senior Lecturer and Programme Coordinator, Department of Languages and Media Studies at Zimbabwe Open \\ University.
}

\begin{abstract}
The process of development is both subversive and addictive. It is subversive because it undermines the status quo and challenges some vested interests. It is also addictive because choice, freedom, knowledge and greater material gain once tasted raises expectations for more of the same expectations that are not easily managed politically. Globalization has become the necessary consequence of economic development which is in pursuit of the modern market economies. As a result there is the development of interconnectedness of the economies in the global village. Failure to link up with the global village is tantamount to economic suicide. It is against this backdrop that African economies cannot afford to be dormant since a nation with a closed economy with no linkages with the rest of the global village will collapse. This research paper is centered on the concept of globalization and economic development in Zimbabwe. Besides reflecting on the impact of globalization on development and democratization, this article explores the various contradictions that arise out of the relationship between these concepts. It also highlights the peculiar challenges that underlie and further complicate this relationship in the specific context of African countries. Any meaningful discussion of these relationships and the attendant contradictions and challenges however, first requires a clear understanding of the relevant concepts. In view of the central focus of this article, it is not only appropriate but also necessary to begin by defining the key concepts. This is not an easy task, considering the diversity of interpretations of the terms 'globalization', 'development' and 'democracy'. Nevertheless, it is to conceptual issues that we first turn our attention.
\end{abstract}

\section{Submitted Date 07 June $2013 \quad$ Accepted Date: 15 June 2013}

\subsection{Globalization}

\section{Conceptual Issues}

There are numerous definitions of the term 'globalization'. Many of these definitions and descriptions however, tend to relate to economic globalization, which is often seen as the main thrust of the concept. Globalization has for instance been defined as a process of integrating economic decision-making... a process of creating a global market place in which, increasingly, all nations are forced to participate. (Kwanashie 2008) It has also been described as 'an ever increasing integration of national economies into the global economy through trade and investment rules and privatization, aided by technological advances. (Adejo 2001)

It is submitted however, that globalization is a much more complex process "with intrinsic, technological, economical, social and political components. (Brysk 2002) Even more appropriate is the definition by Stiglitz (2002) who sees globalization as 'the closer integration of the countries and peoples of the world...the breaking down of artificial barriers to the flow of goods, services, capital, knowledge.... more simplified form of the above definitions is offered by Giddens who sees globalization as a consequence of modernization and defines it as the 'intensification of worldwide social relations which link distant localities in such a way that local happenings are shaped by events occurring many miles away and vice versa.'(Giddens 1990) This definition gives resonance to other related terms that are increasingly gaining popular usage such as the global village, the global economy, the global society and global citizenship. It also echoes Wangwe and Musonda's (2002) definition of globalization as the 'rapidly increasing complex interactions between societies, cultures, institutions and individuals worldwide.

\subsection{Development}

As mentioned earlier, definitions of development are quite diverse. Some emphasize economic development in terms of the growth of national productive capabilities. Others, however, focus on development in terms of human capabilities. For example Amartya Sen (1999) sees development as freedom and argues that it is a process of expanding the real freedoms that people enjoy. He contrasts development as a human freedom with what he calls narrower views of development, such as identifying development with the growth of gross national product, or with the rise in the personal incomes, or with industrialization, or with technological 
advance, or with social modernization. According to Sen (1999) development entails the removal of the things that deprive people of freedom such as poverty, tyranny, poor economic opportunities, social deprivation, neglect of public facilities, intolerance and repressive governance.

The foregoing conception of development is indeed consistent with the definition provided by the 1986 United Nations Declaration on the Right to Development. It defines development as a comprehensive economic, social, cultural and political process, which aims at the constant improvement of the well-being of the entire population and of all individuals on the basis of their active, free and meaningful participation in development and in the fair distribution of benefits resulting there from. Notice that the key point is that is that development only takes place when all individuals are active, free and participate in development.

\subsection{Democracy}

Over the years, democracy has been subjected to various competing definitions and interpretations. This is mainly because philosophers and policy makers sometimes chose to adopt a definition of democracy that they hoped would influence public opinion and solve their problems at the time. It is also because no government wanted to be labeled undemocratic. Eventually a rather simplistic definition of democracy, as 'a government of the people, by the people and for the people' was initially advanced by President Lincoln in 1863 and subsequently embraced by Western scholars.(Ambrose 1995) Thus, according to Thomson(2000) democracy literally means 'rule by people'. Many other commentators have defined democracy along those lines.

Brendalyn Ambrose (1995) defines democracy as 'a system of governance which allows people to freely elect their leaders and hold them accountable, and which provides opportunity for the greater number of people to use their human potential to survive in dignity. (Ambrose 1995). This definition is echoed by David Held who sees democracy as 'a form of government in which, in contradiction to monarchies and aristocracies, the people rule.' (Held 1987) These are all broad definitions of course. Samuel Huntington defines democracy in a narrower political perspective. According to him, a political system is democratic 'to the extent that its most powerful collective decision-makers are selected through fair, honest and periodic elections in which candidates freely compete for votes, and in which virtually all the adult population is eligible to vote. A narrow conception of democracy therefore, limits it to the procedures by which the people select their leaders, whereas a broader interpretation sees it as a political system which allows the people to control public-decision making on an ongoing basis.

It is important to note that whether broad or narrow, most, if not all, definitions of democracy have 'people' as a focal point. As such, in a democratic society, leaders should be chosen by the people, they should be accountable to the people and they should act in the interest of, and on behalf of the people. In a more holistic sense, democracy includes the respect of the rights of the people and the guarantee of equal opportunity for all people. The question, however, is: who are 'the people' envisaged in the definition of the concept of democracy? Which people should partake in and benefit from the democratic process? Should the concept of democracy and its benefits be confined to only citizens of a particular state or be extended to non-citizens. These questions are critical in the context of the relationship between democracy and globalization. In Zimbabwe, for example, although the preamble to the Constitution states categorically that Zimbabwe belongs to all who live in it, political rights (including the right to vote) are exclusively confined to citizens. This type of political exclusion is not unique to Zimbabwe as many other countries have similar provisions in their constitutions. It is submitted that the right to engage in political processes of a state and therefore the right to be among 'the people' envisaged in the concept of democracy should not be confined to citizens only. It should, democratically speaking, be enjoyed by all those who are 'subject to the jurisdiction of the state, its courts and its laws.

\section{The Tensions And The Contradictions}

The implications and impacts of globalization have been widely discussed and debated. Many of the debates have concentrated on the positive contribution made by globalization to economic growth and development on the one hand, and the impoverishment and devastation caused by globalization to the poorer countries on the other. Such debates have therefore focused on the economic dimensions of globalization largely due to the fact that globalization is often erroneously conceived in economic terms.

While the world is striving for democracy and development, there is also a growing realization that globalization is here to stay. What follows is not an extension of the debate on the pros and cons of globalization, but an attempt to highlight the tensions and contradictions that arise in the inevitable relationship between globalization, democracy and development, particularly in the context of the African continent.

\subsection{Globalization and democracy}

To begin with, it could be argued that globalization has a tendency and the potential of narrowing the scope of democracy. One of the inevitable consequences of globalization is the rearrangement of social classes 
by the creation of a dominant capitalist class. When this happens, the sphere of private decision-making expands at the expense of public decision-making. This is a result of the increase in capital's influence over governments and decision-makers. This narrowing of democracy is particularly worrisome in Africa, where problems of social inequality are more severe and social-economic disparities more prevalent.

How globalization affects the state is another important indicator of the tension between globalization and democracy. Accordingly, it has been argued that the widespread disengagement of the state from economic activity (as a result of globalization) has made the state a victim of globalization (Zeleka and McConnaughay 2004). As a result, 'globalization has undercut the conventional national economic as well as political authority of the state," it is further argued. The other side of this argument is that globalization has elevated economic issues into prominence at the expense of democratic concerns. For instance, 'government's important foreign policy decisions are informed more by economic than political considerations. As a result, a situation is emerging where 'both the state and democratic forces are losing effective control over decision-making.

A significant tension between globalization and democracy is what could be referred to as globalized dependency. Africa's growing dependency on Western patronage is well-known. This patronage, an important characteristic of globalization, has a disastrous impact on democracy and governance. Because most of their revenue is generated through such patronage, many African countries are more accountable to the Western donor countries than to their own people. An example is often given of Uganda which, having achieved important advances in terms of poverty alleviation and HIV policies is considered to be an 'effective reformer' and is a recipient of generous international aid packages (Griffith 2003). But the fact that the Uganda government today depends on donors for $53 \%$ of its revenue has clear implications for governance because ultimately the Ugandan government is more answerable to donors than to its citizens (Griffith 2003) The tension between globalization and democracy here is inescapable. The total lack of democracy in Uganda today is testimony to that.

It was mentioned earlier that democracy includes the respect for human rights. A discussion of the tensions between globalization and democracy would therefore be incomplete if it didn't incorporate human rights. In that regard the main contradiction between globalization and human rights is the question as to whether globalization enhances or inhibits the realization of human rights, particularly in the African context.

In attempting an answer to that question, the broad definition of globalization adopted earlier should be kept in mind. If, in terms of that conception, globalization is seen as the closer integration of the countries and peoples of the world, breaking down all fences and barriers leading to the flow of goods, services, capital and knowledge; one would assume then that globalization would bring prosperity to all corners of the globe and with it would come democracy, freedom and human rights. That unfortunately is not the case. The opposite is true. With globalization, the world is experiencing unprecedented levels of conflict accompanied by gross violations of human rights. Africa is home to many of these conflicts with human rights abuses often at the centre of such conflicts.

One of the effects of globalization is that it has turned the world into a global market for goods and services produced and supplied by the powerful transnational corporations and countries of the West. These are mainly driven by the maximization of profit and the underlying capitalist agenda. It can therefore be argued that while there is no doubt about the Western origin of human rights, there is also no doubt that the West will go all out to support the violation of the same human rights if such violation is deemed to be in the best interest of its global capitalist agenda. (Mazrui 2001) Moreover, Western countries are increasingly using their view of human rights as a yardstick to judge developing countries with respect to trade relations and extending development assistance. As a result, 'globalization intensifies impoverishment by increasing poverty, insecurity, fragmentation of society and this violates human rights and human dignity of millions of people.' Clear examples are identifiable in Somalia and the Congo where the West sell arms to African landlords who in turn butcher villages without regard of life and the well- being of the people in these countries. The arm dealers are only concerned on the profits they make without due regard to the suffering that they cause in these countries.

An important contradiction between globalization and human rights is illustrated by the highly political nature of the relationship between the two. There are some who argue that globalization can have only negative social, political and economic effects. As such, globalization undermines human rights. This, according to Rhoda Howard-Hassman, is because people are more likely to enjoy their human rights if they live in a locally, rather than globally-controlled environment. In the African context, this perhaps explains the untold suffering and gross violation of human rights associated with immigration, and human trafficking, both of which are rampant on the continent. It also explains why the worst forms of human rights abuses in Africa were occasioned by slave trade, colonization and apartheid, all of which were a consequence of human movement into or out of Africa. 


\subsection{Globalization and development}

There are many who would argue vehemently in support of globalization and its endless list of benefits. They would point to advances in communications and information technology, global economic integration, international movement of goods and services, technology transfer and increased international trade, to mention but a few. They would then conclude that globalization has enhanced global competitiveness and revolutionized the world economy, and hence, it is the best vehicle for development. Others however, would disagree and point to the severe economic devastation and social instability caused by globalization, particularly in developing countries. Therein lies the tension and contradiction between globalization and development.

In order to understand the contradiction between globalization and development in Africa, it is important to see globalization in the general context of Africa's history. Mulinge and Munyae (2001) have for example argued that globalization is the third phase of colonization, following on the second phase which was neo-colonization. They further argue that the goals of globalization are diametrically opposed to the goals of development in that 'the process of globalization is geared toward the entrenchment of the same forces, processes and structures that hampered the development of Africa under colonial rule.' For them, what distinguishes 'globalization as a form of economic imperialism from the old order (of the $19^{\text {th }}$ and early $20^{\text {th }}$ centuries) is that the colonial powers are no longer competing among themselves but working more or less in unison (Muhinge and Munyae 2001). Taken to its logical conclusion the basis of this argument is that just as there was no real development during colonialism, there is equally none during globalization. Here, real development is seen in the context of the definition given earlier: development that is not measured only in terms of quantitative economic growth but also in terms of its improvement of the lives and well-being of the people. Real development is one that helps to change the living conditions of the people rather than merely increasing the economic wealth of the country.

There is no doubt that globalization has resulted in economic prosperity for developed countries. At the same time however, it has intensified poverty, created unemployment and promoted social disintegration in the majority of developing countries. As a result, there are inevitable but perverse flows of human capital. Ademola Oyejide points out that skilled professionals tend to flow from developing countries to the more developed, thus worsening the global distribution of human capital.

The consequence for the developing counties is obvious. It is for that reason that the United Nations Development Programme pointed out in its 1999 Human Development Report that:

'Rapid technological change and globalization are transforming the world at unprecedented pace, but the benefits are going to the rich and strong rather than the weak and poor... The gap between the wealthy and poor is growing even larger...(UNDP 1999)

Mention was made earlier of Africa's growing dependence on Western countries and the impact of such dependence on democracy and governance. It is submitted that dependence has even greater impact on development. In that context, dependence may be described as a situation in which the economy of certain countries is conditioned by the development and expansion of another economy to which the former is subjected (Irogbe 2005). What this means is that due to unequal power and economic relations, the structure of the dependent economy is shaped more by the requirements of the external economy than by its own domestic needs. As a result, foreign factors of production such as capital and technology have become the determinants of socio-economic progress and political life in most developing countries. Globalization is the lifeblood through which all this takes place.

Other factors that highlight the tension or contradiction between globalization and development in Africa include the role of multinational corporations (whose main goal is to maximize profits) and the role of the Western media (whose main goal is to westernize the rest of the world). But perhaps the most significant factor is, arguably, the role of the so-called Bretton-Woods Institutions (the IMF and the World Bank) in Africa's development. Although many underdeveloped countries greatly distrust the IMF and the World Bank, the very same countries continue to be dependent recipients of huge loans from these institutions. The outrageous interest rates charged have caused unbearable hardships to many of those countries. Moreover the IMF and the World Bank have regularly imposed austerity measures such as structural adjustment programmes (SAPs) on developing countries. These are reform programmes intended to open up poor economies to the global markets through export-led strategies. These programmes are typically accompanied by 'deregulation, an end to price controls and subsidies, currency devaluation, privatization of state enterprises, and sharp cuts in government spending, including cuts in the size of the civil service. A case in point is what happened in Zimbabwe from 1980 to 2006 when the West looted as much as they could, but when the indigenous demanded the redistribution of land then the government of Zimbabwe became a pariah state. The table below illustrate the developments that took place in Zimbabwe during the period 1980 to 2006 
Table 1 Government Economic policy: 1980 to 2006

\begin{tabular}{|c|c|c|c|}
\hline Period & Policy Regime & Features & Impact \\
\hline 1991-1995 & $\begin{array}{ll}\text { Economic } & \text { Structural } \\
\text { Adjustment } & \\
\text { Programme(ESAP) } & \end{array}$ & $\begin{array}{l}\text { 1. Market processes through } \\
\text { removal of controls. } \\
\text { 2. Devaluation of the } \\
\text { Zimbabwean dollar. } \\
\text { 3. Export promotion } \\
\text { programmes } \\
\text { 4.Proactive } \\
\text { policies. }\end{array}$ & $\begin{array}{l}\text { 1. Healthy balance of } \\
\text { payments, more external } \\
\text { finance to support the } \\
\text { productive sector. } \\
\text { 2. Diminished exports and } \\
\text { higher imports offset by } \\
\text { donor financing. }\end{array}$ \\
\hline $1998-2000$ & $\begin{array}{lrr}\text { Zimbabwe Programme for } \\
\text { Economic and Social } \\
\text { Transformation (ZIMPREST) }\end{array}$ & $\begin{array}{l}1 \text { Continuation of the ESAP } \\
\text { prescription with mitigation } \\
\text { measures of the adverse } \\
\text { effects. } \\
2 \text { Reduction of budget deficit } \\
3 \text { Control inflation } \\
4 \text { Social transformation } \\
5 \text { International cooperation }\end{array}$ & $\begin{array}{l}\text { 1. Never implemented since } \\
\text { IMF and World Bank } \\
\text { indicated that targets were not } \\
\text { met. } \\
\text { 2.Stalled negotiations over } \\
\text { land reform funding with the } \\
\text { British } \\
\text { 3. Steep deterioration of } \\
\text { economy }\end{array}$ \\
\hline
\end{tabular}

\begin{tabular}{|c|c|c|c|}
\hline Period & Policy Regime & Features & Impact \\
\hline $2000-2002$ & $\begin{array}{lr}\begin{array}{l}\text { Millennium } \\
\text { Recovery }\end{array} & \text { Economic } \\
\text { (MERP) } & \end{array}$ & $\begin{array}{l}\text { 1.Restoring micro -economic } \\
\text { stability } \\
2 \text {. Controlling inflation } \\
3 \text { Capital expenditure and social } \\
\text { services. } \\
4 \text { Enhanced infrastructure } \\
\text { development } \\
5 \text { Restore international } \\
\text { cooperation. }\end{array}$ & $\begin{array}{l}\text { 1. Programme was overtaken } \\
\text { by events when there was no } \\
\text { positive response from donors } \\
\text { and multinational institutions. } \\
2 \text { Decline of real wages and no } \\
\text { growth in GDP. } \\
\text { 3. High unemployment. }\end{array}$ \\
\hline $2003-2004$ & $\begin{array}{l}\text { National } \\
\text { recovery } \\
(\mathrm{NERP})\end{array}$ & $\begin{array}{l}\text { 1 Biased towards agriculture. } \\
\text { 2. Subsidies in the agricultural } \\
\text { sector. } \\
\text { 3. Support of the informal } \\
\text { sector. } \\
\text { Combating HIV and AIDS } \\
\text { 4. De-racialising of the } \\
\text { economic sectors }\end{array}$ & $\begin{array}{l}\text { 1Targets have not been met } \\
\text { and continued economic } \\
\text { meltdown of the country on all } \\
\text { indicators. (increased poverty } \\
\text { levels, high unemployment, } \\
\text { lack of foreign currency } \\
\text { exchange and unserviced } \\
\text { international debts. }\end{array}$ \\
\hline 2004 to 2006 & Monetary policy statement & $\begin{array}{l}\text { Government seek to resuscitate } \\
\text { the economy through clean up } \\
\text { of the financial sector, support } \\
\text { to agricultural recovery and anti } \\
\text { corruption blitz. }\end{array}$ & $\begin{array}{l}\text { Signs of economic recovery as } \\
\text { inflation decreases from a high } \\
\text { of } 622 \text { per cent by November } \\
2003 \text { to } 326 \text { per cent by } \\
\text { August } 2004\end{array}$ \\
\hline
\end{tabular}

\section{Sources: Government of Zimbabwe 1998, 2000; UNECA 2003; CSO, 2002}

They are also blamed for entrenching inequalities between and within countries (Mlambo \& Pangeti 2001). It has also been argued that as a result of their activities, 'the IMF and the World Bank have institutionalized economic stagnation in the underdeveloped countries. (Irogbe 2005). Needless to mention that nowhere is the impact of the IMF and World Bank machinations felt more intensely than on the African continent. Needless to add, that the African people have globalization to thank for all this. It is clear from the foregoing discussion that certain tensions and contradictions do exist between development, democracy and globalization. In Africa, these tensions and contradictions are exacerbated by several challenges that are prevalent and unique to African countries. It is to those challenges that we now turn our attention. The table above clearly shows how the question of globalization affected Zimbabwe. Although there were other polical factors that came into play, there is enough evidence to show that to a certain extent the collapse of the economy by 2000 had something to do with the effects of globalization since the Western nations united against the Zimbabwean government that was trying to redistribute land to the indigenous people.

\section{Conflicts}


One of the main challenges underlying the relationship between development, democracy and globalization is in the form of the never-ending regional and internal conflicts. Today, there are several on-going conflicts in various African countries including Somalia, Ivory Coast, the Democratic Republic of Congo (DRC), Sudan and Uganda, to name but a few. In all there are more than 20 recent or on-going conflicts of one form or another on the African continent. There are several factors often mooted as causes of these conflicts. One such factor is poverty. It has been argued however, that poverty 'does not simply exist but is created by the manner in which a region is integrated into the global economy. Tandon argues that the process of globalization breeds violence and conflict when it continues to produce inequality, poverty, environmental destruction and unprecedented concentration of economic power for a few while the majority are marginalized and excluded. This is how Africa has become a victim of globalization.

It has been opined that some of the deadliest conflicts that have taken place in Africa in the recent past can be traced to the expansion and domination of transnational corporations. Examples are usually given of the perpetual war in the oil-rich Niger Delta, the long-standing civil war in Angola involving 'blood diamonds' and the ongoing conflict in the DRC centered on the exploitation of the rich mineral reserves. ( Dare ) The same may be said of the recent conflicts in Sierra Leone, Nigeria, Sudan, Liberia and the Great Lakes where people have taken up arms to fight in oil, diamond and copper wars. Those arms themselves moreover are supplied by none other than transnational corporations and foreign governments. The role of transnational corporations, as agents of globalization, in the escalation of conflict and violations of human rights in Africa cannot be overemphasized. The negative impact on democracy and development is pretty obvious.

\subsection{Poverty}

Poverty, as mentioned earlier is one of the greatest African challenges in the face of globalization. Indeed Africa is generally a continent of extreme poverty. It is estimated for example, that about 315 million of the 700 million people who live in sub-Saharan Africa survive on less than one dollar per day. Statistics also show that one third of the African population (about 184 million people) suffer from malnutrition, less than 50\% have access to hospitals or doctors, the average life expectancy is 41 years, and one in six children dies before the age of five. It is further estimated that the total annual gross national product (GNP) of all African countries is about US\$300 billion (roughly the same as that of Belgium) of which more than $50 \%$ is contributed by South Africa and Nigeria alone.(World Bank) The levels and extent of poverty and its effect on the African people cannot therefore be over emphasized.

The length and depth of this paper do not lend themselves to a detailed discussion of the causes of poverty in Africa. Suffice to say that globalization has, in various ways, contributed significantly to the extent and impact of poverty on the African continent. In that regard, it has been argued that the structural imbalance at the global level and the old-fashioned social and economic structures in developing countries such as those that form the African continent, interact to aggravate poverty in those countries. Take the problem of African debt as for example. It is estimated that today, African states owe foreign creditors an estimated US\$300 billion. To service this debt, African states must come up with some US \$15 billion each year. (Nagan ) Another example is the perpetual agricultural crisis facing African countries. This crisis is created by, among other things, the protectionist policies of the rich Western countries. These countries 'operate a battery of tariff and non-tariff barriers (duties, quotas, subsidies to domestic producers) against agricultural products from the Third World. Such practices inevitably hurt African agriculture leading to a decline in per capita production and thereby increasing poverty.

The link between poverty, human rights, democracy and development is the basis of a largely complex but extremely important relationship. At the heart of that relationship is the recognition that poverty is not only a denial of human rights, but it also undermines democracy and reverses the gains of development. In the age of globalization, that relationship is not only complex and important but also potentially contradictory. Nowhere is this more real than on the African continent.

\subsection{HIV/AIDS and other diseases}

According to the 2007 UNAIDS/WHO AIDS Epidemic Update, Sub-Saharan Africa remains the region most affected by the AIDS epidemic and is home to two thirds (68\%) of all people infected with HIV worldwide. (UNAIDS 2007) It is estimated that $50 \%$ to $80 \%$ of tuberculosis patients in Southern Africa are also HIV positive. Indeed TB is such a serious problem that it is considered to be responsible for about 1500 deaths everyday in Africa. In 2005, the WHO Africa Regional Committee adopted a resolution declaring TB an emergency on the continent. Equally serious is the problem of malaria; so serious in fact that $90 \%$ of the estimated malaria deaths worldwide occur in Africa. One in every five childhood deaths is caused by malaria and it is estimated that the disease costs Africa more than \$12 billion in lost GDP every year.

The link between the above mentioned diseases and development is easy to establish. So too is the link between such diseases and the enjoyment of human rights, particularly socio-economic rights such as the right 
of access to health care services. Much less obvious however, is the link between HIV/AIDS, TB or malaria and globalization. It may be argued though that the ability of African countries to respond to these diseases is dependent on their ability to climb out of poverty, enjoy favorable terms of trade, implement and control fair patent policies on medications, all of which are issues linked to globalization. An argument could be made in favor of globalization and its contribution to addressing health problems in Africa through the role of the Global Fund to Fight AIDS, Tuberculosis and Malaria for example. Indeed there is no denying that such initiatives have had some positive outcomes. However, these outcomes do not reach the rural poor who form about $80 \%$ of African populations. Moreover, besides the usual strings attached and the problem of 'globalized dependency' that was referred to earlier, such initiatives usually fail to achieve the intended results. For example in Uganda, grants from the Global Fund were stopped in August 2005 when serious financial irregularities were discovered within the Programme Management Unit of the Ministry of Health. $\underline{58}$ This indeed is yet another African challenge, to which we now turn our attention.

\section{Conclusion}

The advocates of globalization will no doubt quickly point to the benefits of globalization and its positive contribution to economic growth and development worldwide. Critics however, will disagree and point to the impoverishment and devastation caused by globalization particularly in poor countries. It is clear that due to the various tensions between globalization, development and democracy, the benefits of globalization will not only remain elusive to many African countries, but globalization may indeed undermine human rights, impede development and be a threat to democracy in those countries. Moreover in the face of the unique challenges faced by African countries, while the Western world will continue to be winners in the race for the benefits of globalization, most African counties will continue to be relegated to the position of losers.

\section{Bibliography}

[1]. Adejo A M (2001) 'The roots of globalization: A historical review' 1(1) Journal of and International Studies 4.

[2]. Ambrose B O (1995) Democratization and the protection of human rights in Africa

[3]. Assefa T, Rugumamu S M \& Ahmed A G M (2001) Globalization, democracy and development in Africa: Challenges and prospects

[4]. Brysk A (2002 (Ed) Globalization and human rights)

[5]. Giddens A (1990) The consequences of modernity

[6]. Griffith P (2003) Unbinding Africa: Making globalization work for good governance (

[7]. Held D1987) Models of Democracy

[8]. Howard-Hassman R E 2005 'The second great transformation: Human rights leapfrogging in the era of globalization' (27) Human Rights Quarterly 16

[9]. K Irogbe (2005) 'Globalization and the development of underdevelopment in the third world' (22 (1) Journal of Third World Studies 42

[10]. Klitgaard R(1991) 'Political Corruption: Strategies for Reform’ 2(4) Journal of Democracy 86

[11]. Le Roux W (2009 'Migration, street democracy and expatriate voting rights') 24(2) SA Public Law 370

[12]. Mbaku J M(2007) Corruption in Africa: Causes, consequences and cleanups

[13]. Okogbule N S 'Globalization, economic sovereignty and African development: From principles to realities' (2008) 25(1) Journal of Third World Studies 215

[14]. Semboja J, Mwapachu J \& Jansen E(2002) (Eds) Local perspectives on globalization: The African case Sen A Development as freedom

[15]. Stiglitz J (2002) Globalization and its discontents Thomson A An introduction to African politics

[16]. Zeleza P T \& McConnaughay P J (2004) Human rights, the rule of law and development in Africa 